\title{
Role of Interleukin-10 in T Helper Cell Dysfunction in Asymptomatic Individuals Infected with the Human Immunodeficiency Virus
}

\author{
Mario Clerici, * Thomas A. Wynn, Jay A. Berzofsky," Stephen P. Blatt, " Craig W. Hendrix," \\ Alan Sher," Robert L. Coffman," and Gene M. Shearer* \\ ${ }^{*}$ Experimental Immunology and ${ }^{\ddagger}$ Metabolism Branches, National Cancer Institute, and ${ }^{\S}$ Laboratory of Parasitic Diseases, National \\ Institute of Allergy and Infectious Diseases, National Institutes of Health, Bethesda, Maryland 20892; "DNAX Research Institute, Palo \\ Alto, California 94304; and "HIV Unit, Wilford Hall Medical Center, Lackland Air Force Base, San Antonio, Texas 78236
}

\begin{abstract}
The loss of T helper cell (TH) function in asymptomatic HIV type 1-infected individuals occurs before the decline in $\mathrm{CD4}^{+} \mathrm{T}$ cells. At least part of the loss in $\mathrm{TH}$ function results from changes in immunoregulatory cytokine profiles. To investigate the role of IL-10 in such dysregulation, we tested whether: $(a)$ expression of IL-10-specific mRNA would be upregulated in PBMC from asymptomatic, $\mathrm{HIV}$-infected $\left(\mathrm{HIV}^{+}\right)$individuals; (b) PBMC from these same individuals would produce increased levels of IL-10 when stimulated in vitro with phytohemagglutinin; and $(c)$ defective antigen-specific TH function could be restored by anti-IL-10 antibody. We observed that IL-10-specific mRNA was marginally upregulated, and increased levels of IL-10 were produced by PBMC from $\mathrm{HIV}^{+}$ individuals compared with PBMC from uninfected individuals. Those individuals whose TH function was more severely compromised produced higher levels of IL-10. Additionally, defective antigen-specific TH function in vitro could be reversed by anti-IL-10 antibody, including the response to HIV envelope synthetic peptides. Furthermore, the antigen-specific TH responses of HIV-uninfected PBMC could be reduced with IL10, a process reversed by anti-IL-10. These results confirm that the early loss of $\mathrm{TH}$ function in $\mathrm{HIV}^{+}$individuals is due at least in part to cytokine-induced immune dysregulation, and support the hypothesis of a switch from a predominant type 1 state to a predominant type 2 condition in HIV infection. ( $J$. Clin. Invest. 1994. 93:768-775.) Key words: cytokines • interleukin-2 - interleukin-10 • human immunodeficiency virus infection $\cdot T$ lymphocytes
\end{abstract}

\section{Introduction}

The most dramatic effect of infection with HIV type 1 on the immune system is the severe depletion of $\mathrm{CD}^{+}{ }^{+} \mathrm{T}$ cells. However, other less obvious effects have been reported that affect immunity, particularly $T$ cell function (1-5). Thus, PBMC from HIV-infected, asymptomatic $\left(\mathrm{HIV}^{+}\right)^{1}$ individuals can ex-

Address correspondence to Gene M. Shearer, Ph.D., Experimental Immunology Branch, National Cancer Institute, Building 10, Room 4B17, National Institutes of Health, Bethesda, MD 20892. 1993.

Received for publication 21 May 1993 and in revised form 9 August

1. Abbreviations used in this paper: ALLO, HLA-disparate PBMC; APC, antigen-presenting cell; env peptides, HIV envelope synthetic peptides; FLU, influenza A virus; $\mathrm{HIV}^{+}$, HIV-seropositive; $\mathrm{HIV}^{-}$, HIV-seronegative; REC, recall antigens; RT, reverse transcription; TH, $T$ helper cell.

The Journal of Clinical Investigation, Inc.

Volume 93, February 1994, 768-775 hibit defects of in vitro antigen- or mitogen-stimulated proliferation or IL-2 production (4), despite adequate numbers of $\mathrm{CD}^{+}{ }^{+} \mathrm{T}$ cells. We have studied more than $1,000 \mathrm{HIV}^{+}$individuals, many of whom have been followed longitudinally for up to $5 \mathrm{yr}(4,6,7)$. Among $\mathrm{HIV}^{+}$individuals with $\mathrm{CD}^{+} \mathrm{T}$ cell counts ranging between 400 and 800 , we observed four patterns of T helper cell ( TH) dysfunction, based on the ability of their PBMC to respond by IL-2 production or proliferation to a panel of stimuli and independent of the number of $\mathrm{CD}^{+} \mathrm{T}$ cells (4). These stimuli included: $(a)$ the recall antigens (REC), influenza A virus (FLU), tetanus toxoid, and HIV envelope synthetic peptides (env peptides) $(8)$; (b) HLA-disparate PBMC (ALLO); and (c) PHA. The four observed patterns and their frequencies were: (1) REC+/ALLO+/ $\mathrm{PHA}+([+/+/+])(36 \%) ;(2) \mathrm{REC}-/ \mathrm{ALLO}+/ \mathrm{PHA}+([-/$ $+/+]) \quad(41 \%) ;$ (3) REC-/ALLO-/PHA+ $([-/-/+])$ (11\%); and (4) REC-/ALLO-/PHA- $([-/-/-])(12 \%)$. These four $\mathrm{TH}$ response patterns were sequential and progressive in the order of 1 to 4 . The loss of in vitro TH function was associated with a more rapid decline in CD4 count (6), progression to AIDS diagnosis, and progression to death (7).

We recently reported that the selective loss of ability to produce IL- 2 in response to REC (a memory $T$ cell response) $([-/+/+])$ was associated with an increase in IL-4 production (9). We found that the in vitro production of IL-2 in response to FLU, but not to env peptides, could be reconstituted by addition of anti-IL-4 antibody to the cultures (9). This is consistent with the demonstration in humans $(10,11)$ and mice (Powrie, F., D. Menon, and R. L. Coffman, manuscript submitted for publication) that IL-4 is an important component of the inhibition of TH1 responses by $\mathrm{TH} 2$ cells. We also observed that the next sequential stage of TH dysfunction characterized by $[-/-1+]$ was associated with loss of IL-2 production in response to REC and ALLO, and of IL-4 production in response to $\mathrm{PHA}$ (9). This latter observation raised the possibility that another cross-regulatory cytokine is involved in the suppression of TH responses assessed by IL- 2 production and proliferation. Because IL-10 has been demonstrated to have appreciable $\mathrm{T}$ cell inhibitory activity, particularly on TH1 cells in mice and humans (13-20), we studied the possible role of IL-10 in the more functionally advanced stages of HIV infection. We demonstrate in the present report that the expression of IL-10-specific mRNA and the production of PHA-stimulated IL- 10 are increased in $\mathrm{HIV}^{+}$individuals, and that those individuals whose $\mathrm{TH}$ function was most severely compromised (assessed by proliferation and IL-2 production) produced proportionally higher levels of IL-10. We also show that neutralization of endogenous IL-10 can restore IL-2 production in response to recall antigens, including the TH response to HIV env peptides. Finally, we verify the inhibitory properties of IL-10 in our system by demonstrating that IL-10 can abro- 
gate or reduce the in vitro response of PBMC from HIV-uninfected $\left(\mathrm{HIV}^{-}\right)$individuals, and that anti-IL-10 antibody can reverse this process. These findings are discussed in the context of the hypothesis that a type 1-to-type 2 functional switch occurs in asymptomatic $\mathrm{HIV}^{+}$individuals as they progress toward AIDS.

\section{Methods}

Patient and control blood. The HIV ${ }^{+}$individuals were from Wilford Hall, Lackland Air Force Base, San Antonio, TX. HIV ${ }^{-}$control donors were obtained from Wilford Hall and the Transfusion Department, National Institutes of Health. The blood samples were collected under protocols approved by both institutions. Whole blood was collected in vacutainer tubes containing preservative-free heparin (Becton Dickinson \& Co., Mountain View, CA). PBMC were separated on lymphocyte separation medium (Organon Teknika, Rockville, MD), were washed twice in PBS, and the number of viable leukocytes was determined by trypan blue exclusion and hemocytometer. The cells were resuspended at $3 \times 10^{6}$ cells $/ \mathrm{ml}$ in RPMI 1640 (Gibco Laboratories, Grand Island, NY) containing $100 \mathrm{U} / \mathrm{ml}$ penicillin and $2 \mathrm{mM}$ glutamine.

Detection of IL-10 mRNA. Quantitation of IL-10 mRNA expression was done as follows. Relative quantities of mRNA for IL-10 and hypoxanthine guanine ribosyl transferase as a control were assessed by a quantitative reverse transcriptase-PCR protocol as described previously $(9,21)$. Briefly, total cellular RNA was isolated from PBL of $\mathrm{HIV}^{+}$individuals either unstimulated or stimulated with PHA for $6 \mathrm{~h}$ by lysis of the cells with an RNA solvent (RNAzol; Tel Test, Inc. Friendswood, TX). $1 \mu \mathrm{g}$ of RNA was reverse transcribed (RT) and then was amplified (thermus aquaticus DNA polymerase; Promega Corp., Madison, WI). A 1:8 dilution of each cDNA was prepared, and $10 \mu \mathrm{l}$ was used in the PCR. PCR products were run on a $1 \%$ agarose gel and were transferred to a nylon membrane (Hybond $\mathrm{N}+$; Amersham International, Buckinghamshire, UK). Southern blots were hybridized with internal cytokine-specific oligonucleotide probes labeled by an enhanced chemoluminescence system (ECL; Amersham International ). Light output was detected on Hyperfilm-ECL, was analyzed on a scanner (model 600ZS; Microtek International, Torrance, CA) calibrated with a densitometric step tablet (Eastman Kodak, Rochester, NY), and was adjusted relative to the corresponding hypoxanthine guanine ribosyl transferase signal when necessary to normalize for RNA levels used in the RT reaction. The amount of PCR product was determined by comparison of signal density with that of standard curves generated from simultaneously amplified serial twofold dilutions of RT product from samples with high amounts of IL-10 mRNA. Primer and probe sequences for IL-10 were as described previously (22).

IL-2 production and proliferation. The ability of PBMC to produce antigen-induced IL-2 or to proliferate was determined by culturing the PBMC at $37^{\circ} \mathrm{C}$ in a moist, $7 \% \mathrm{CO}_{2}$ atmosphere. PBMC were either unstimulated or were stimulated with: FLU (A/Bangkok RX73 $\mathrm{H} 3 \mathrm{~N} 2$ ) ( 1:500 concentration); $2 \times 10^{5} /$ well 50-Gy irradiated allogeneic PBMC from unrelated $\mathrm{HIV}^{-}$donors (ALLO); PHA diluted 1:100 (Gibco Laboratories); or a pool of five synthetic peptides $(2.5 \mu \mathrm{M}$ final concentration) from env peptides of HIV-1 (T1, T2, Th4.1, P18IIIB, P18MN) previously shown to be recognized by $T$ lymphocytes from asymptomatic $\mathrm{HIV}^{+}$individuals and recombinant gp160-vaccinated volunteers $(8,23-26)$. For IL-2 production, $3 \times 10^{5} \mathrm{PBMC}$ were cultured in 96-well, flat-bottomed culture plates (Costar Corp., Cambridge, MA) for $7 \mathrm{~d}$ in the presence of $2 \mu \mathrm{g} / \mathrm{ml}$ of the human anti-IL-2 receptor antibody anti-Tac to prevent IL- 2 consumption by the stimulated cells (27) (provided by Dr. John Hakimi, Hoffman-La Roche, Nutley, NJ). For IL-2 production, culture supernatants were frozen and stored at $-20^{\circ} \mathrm{C}$ until assayed for IL-2 content. The IL-2 assays consisted of culturing $8 \times 10^{3}$ of the IL-2-dependent CTLL cell line per well in 96-well, flat-bottomed microtiter plates, in the presence of four twofold dilutions of unstimulated or antigen-stimulated culture supernatants as described previously (4). $24 \mathrm{~h}$ later, the cultures were pulsed with $1 \mu \mathrm{Ci}$ of $\left[{ }^{3} \mathrm{H}\right]$ thymidine and were harvested after $18 \mathrm{~h}$ using a 96-well cell harvester (Tomtec, Orange, CT). ${ }^{3} \mathrm{H}$ determinations were made using a beta-plate spectrometer (Pharmacia LKB Biotechnology Inc., Piscataway, $\mathrm{NJ}$ ).

In the assays in which augmentation of defective FLU-, ALLO-, PHA-, or env peptides-stimulated proliferation of $\mathrm{HIV}^{+} \mathrm{PBMC}$ was induced by anti-IL-10, anti-IL-4, or anti-IL-10 plus anti-IL-4 antibodies, PBMC were stimulated for $5 \mathrm{~d}$ in the absence or in the presence of 5 $\mu \mathrm{g} / \mathrm{ml}$ anti-IL-10 (JES3-19F1; DNAX, Palo Alto, CA), $5 \mu \mathrm{g} / \mathrm{ml}$ antiIL-4 (MP4-25D2; DNAX), or $5 \mu \mathrm{g} / \mathrm{ml}$ anti-IL-10 plus $5 \mu \mathrm{g} / \mathrm{ml}$ antiIL-4 antibodies; anti-TGF- $\beta$ antibody (R\&D Systems, Inc., Minneapolis, $\mathrm{MN})(5 \mu \mathrm{g} / \mathrm{ml})$ was used as a control.

For experiments in which cytokine-mediated suppression of TH function was attempted, PBMC from $\mathrm{HIV}^{-}$controls were preincubated for $3 \mathrm{~h}$ with human IL-4 (hIL-4; DNAX) (final concentration 5 $\mathrm{ng} / \mathrm{ml}$ ), hIL-10 (DNAX) (final concentration $5 \mathrm{ng} / \mathrm{ml}$ ), or recombinant gp120 (rgp120 IIIB strain; American Bio-Technologies Inc., Cambridge, MA) (final concentration $4 \mu \mathrm{g} / \mathrm{ml}$ ) before stimulation with FLU, ALLO, or PHA. To restore TH function suppressed in this manner, PBMC from HIV - controls preincubated with hIL-4, hIL-10, or rgp 120 were stimulated with antigens in medium alone or in medium containing an anti-IL-4 (MP4-25D2) (DNAX) or an anti-IL-10 (JES3-19F1; DNAX) antibody (final concentration for both antibodies of $5 \mu \mathrm{g} / \mathrm{ml}$ ).

IL-10 production. The ability of PBMC samples to produce mitogen-induced IL- 10 was determined by culturing $3 \times 10^{6} \mathrm{PBMC} /$ well in a 24-well LINBRO plate (Flow Laboratories, Inc., McLean, VA) at $37^{\circ} \mathrm{C}$ in a moist, $7 \% \mathrm{CO}_{2}$ atmosphere. PBMC were stimulated with PHA diluted 1:100 (Gibco Laboratories). The culture media consisted of RPMI 1640 (Gibco Laboratories). Supernatants were harvested after $48 \mathrm{~h}$ of culture, and were frozen and stored at $-20^{\circ} \mathrm{C}$ until assayed for IL- 10 content. The supernatants were harvested after $48 \mathrm{~h}$ as it has been previously shown that this is the optimal time for detection of IL-10 produced by human PBMC stimulated with PHA (25). The amount of IL-10 present in the supernatants was determined using a two-step ELISA (28). Briefly, Immulon plates (Dynatech Laboratories Inc., Chantilly, VA) were coated overnight at $4^{\circ} \mathrm{C}$ with $100 \mu \mathrm{l} /$ well of the antibody JE53-9D7 (DNAX) (final concentration $5 \mu \mathrm{g} / \mathrm{ml}$ ). Plates were washed five times in PBS-Tween. The plates were blocked with $150 \mu \mathrm{l}$ of $10 \% \mathrm{FCS}$ in PBS incubated at $37^{\circ} \mathrm{C}$ for $1 \mathrm{~h}$ and then were washed five times with PBS-Tween. Supernatants were diluted through three serial dilutions $(1: 2-1: 8)$ in PBS-Tween, which contained the 4-hydroxy-3-iodo-5-nitrophenylacetic acid (NIP)-conjugated antiIL-10 antibody NIP-JES3-12G8 (DNAX) (final concentration $0.5 \mu \mathrm{g} /$ $\mathrm{ml}$ ) as well as the rat IgG antibodies GL 113 (IgG1) and GL 117 ( $\operatorname{lgG} 2$ ) (1:50 dilution) to inhibit rheumatoid factor activity. A 100- $\mu$ l aliquot of each sample was added to each well and was incubated at $37^{\circ} \mathrm{C}$ for $1 \mathrm{~h}$, and a standard for IL-10 was run concurrently. Plates were washed with PBS-Tween five times. Horseradish peroxidase antiIL-10-conjugated antibody (J4-HRP) was diluted 1:3,000 in PBS, and $100 \mu \mathrm{l}$ was added to each well and incubated for $1 \mathrm{~h}$ at $37^{\circ} \mathrm{C}$. Plates were again washed with PBS-Tween. 2,2'-Azinobis (3-ethyl benzthiazoline sulfonic acid) was diluted $1: 1$ with $\mathrm{H}_{2} \mathrm{O}_{2}$ (Kirkegaard \& Perry Laboratories, Inc., Gaithersburg, MD), and $100 \mu \mathrm{l}$ of this mixture was added to each well. Plates were developed for $15 \mathrm{~min}$ and then were read in an ELISA reader (Molecular Devices Corp., Menlo Park, CA) at a wavelength of $405 \AA$. Values for IL-10 were calculated from a standard curve of recombinant human IL-10.

$T$ cell phenotyping. Peripheral blood from $\mathrm{HIV}^{+}$individuals was consistently drawn between 7:00 and 9:00 a.m. daily by venipuncture into tubes containing $\mathrm{K}_{3}$ EDTA to minimize the effect of diurnal variation on $\mathrm{CD}^{+} \mathrm{T}$ cell measurements. Labeling with fluorochrome-conjugated monoclonal antibodies against CD3 (T3), CD19 (B4), CD56 (NKH-1), CD4 (T4-FITC), CD8 (TD8-FITC), CD4 and CD29 (4B4$\mathrm{PE}$ ), CD4 and CD45R (2H4-PE), CD4 and DR (I2/I3), and CD8 and DR (Coulter Immunology, Hialeah, FL) was performed by taking 100 


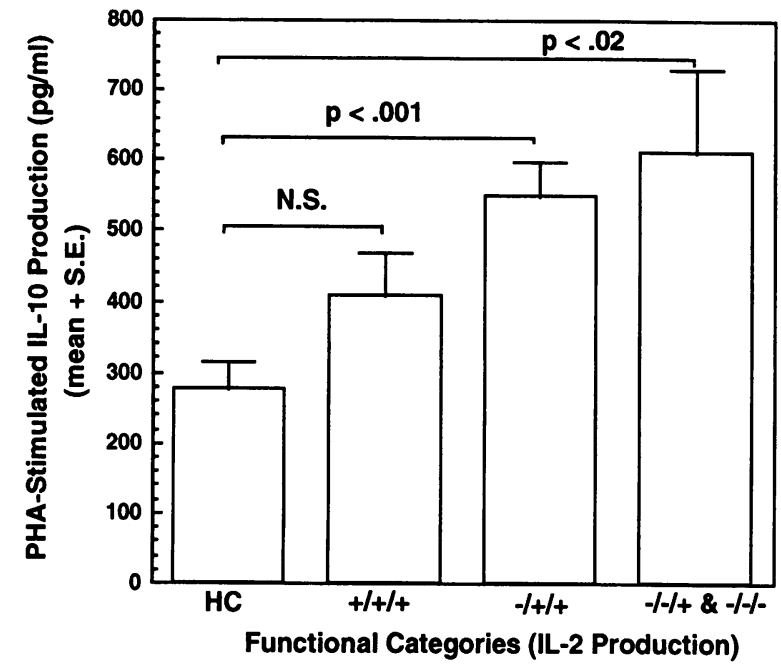

Figure 1. Mean value of PHA-stimulated IL-10 production (picograms per milliliter) by PBMC from HIV - healthy controls $(H C)(n$ $=11$ ), or from $\mathrm{HIV}^{+}$individuals whose $\mathrm{TH}$ functional patterns were: $[+/+/+](n=22) ;[-/+/+](n=28) ;[-/-/+](n=5) ;$ and $[-/-/-](n=6)$. The bars indicate standard errors.

$\mu \mathrm{l}$ of a whole blood sample for each surface marker to be identified and by incubating it with $10 \mu$ l of the corresponding monoclonal antibody. Samples were mixed, were incubated at room temperature for $30 \mathrm{~min}$, and then were processed in an immunology work station (Q-prep; Coulter Immunology). Flow cytometry was performed with a flow cytometer (Epics; Coulter Immunology), as described previously (29). All specimens were processed in tandem with both a fresh whole blood specimen and a cryopreserved lymphocyte preparation from $\mathrm{HIV}^{-}$ donors.

\section{Results}

Analysis of IL-10 mRNA expression and IL-10 production by PBMC from $\mathrm{HIV}^{+}$individuals. To demonstrate that IL-10 is increased in $\mathrm{HIV}^{+}$individuals, we assessed the relative levels of IL-10 mRNA expression induced by stimulation with PHA. A low constitutive level of IL-10 mRNA expression was detectable in samples from both the HIV ${ }^{-}$healthy controls and $\mathrm{HIV}^{+}$individuals. Upon stimulation with PHA, the $[-/+1+$ and $-/-/+;-/-/-$ H HV $^{+}$TH functional categories produced an average twofold more IL-10 mRNA than the control group (data not shown).
We also stimulated PBMC in vitro with PHA to test whether IL- 10 produced by $\mathrm{HIV}^{+}{ }^{+}$individuals who exhibit $\mathrm{TH}$ defects by IL-2 production is increased compared with that produced by $\mathrm{HIV}^{-}$healthy control donors. Because fewer individuals were found who show the most severe defects of TH dysfunction $[-/-/+$ and $-/-/-](4)$, data from the $[-/-/$ $+]$ and the $[-/-/-]$ patients were combined. PBMC from 11 $\mathrm{HIV}^{-}$healthy controls and $61 \mathrm{HIV}^{+}$individuals were characterized by TH function as follows: $22[+/+/+] ; 28[-/+/+]$; $5[-/-/+]$; and $6[-/-/-]$. The mean amount of IL-10 produced by each of the groups was: $\mathrm{HIV}^{-}$controls, $275 \mathrm{pg} /$

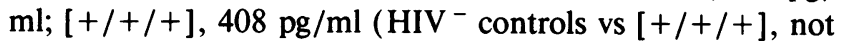
significant by two-tailed Student's $t$ test $) ;[-/+/+], 546 \mathrm{pg} /$ $\mathrm{ml}\left(\mathrm{HIV}^{-}\right.$controls vs $\left.[-/+/+], P>0.001\right) ;[-/-/+]$ and $[-/-/-], 619 \mathrm{pg} / \mathrm{ml}^{(\mathrm{HIV}}{ }^{-}$controls vs $[-/-/+]$and $[-/-/$ $-], P>0.02$ ). These results are summarized in Fig. 1. All of the HIV ${ }^{+} \mathrm{TH}$ functional categories produced more IL-10 than the HIV - healthy control group. There was a gradual increase in IL-10 production with increasing severity of $\mathrm{TH}$ defects defined by absence of IL-2 production, with the most severely impaired categories $([-/-/+]$ and $[-/-/-])$ showing a slightly greater than twofold increase in IL-10 above the control group. No correlation was observed between IL-10 production and the clinical stage of the patients. To further investigate whether a correlation could be established between IL-10 production and changes in lymphocyte subpopulations, we analyzed the PBMC of all $61 \mathrm{HIV}^{+}$individuals that were functionally characterized by FACS $^{\circledR}$ techniques using a panel of CD markers. As shown in Table I, no correlation was seen between any of the CD markers and IL-10 production, although a trend toward a lower percentage of $\mathrm{CD} 4{ }^{+}$lymphocytes and a higher percentage of $\mathrm{CD} 19^{+}$lymphocytes was seen in the $[-/-/+$ and $-/-/-$ ] subset of patients.

Restoration of TH function in $\mathrm{HIV}^{+}$individuals with anti$I L-10$. The above results demonstrate an increase in IL-10 production in $\mathrm{HIV}^{+}$individuals who exhibit defects in proliferation and production of IL-2 in response to one or more stimuli. We also tested whether the defective $\mathrm{TH}$ function of $\mathrm{HIV}^{+}$ individuals could be increased in vitro by stimulating their PBMC in the presence of anti-IL-10, anti-IL-4, or anti-IL-10 plus anti-IL-4. The proliferative responses of four $\mathrm{HIV}^{+}$individuals are shown in Fig. 2. In two examples, reduced but positive FLU responses were elevated three- to eightfold (Fig. 2, $A$ vs. $B$ and $E$ vs. $F$ ). In the third example, a 10 -fold improvement in the FLU-stimulated proliferative response resulted in the conversion of $\mathrm{a}[-/+1+]$ proliferative response to $\mathrm{a}[+/+1$

Table I. Cytokine Production and Phenotypic Markers of PBMC from $61 \mathrm{HIV}^{+}$Individuals

\begin{tabular}{|c|c|c|c|c|c|c|c|c|c|}
\hline IL-2 functional status & IL-10 & $\mathrm{CD} 4$ & $\mathrm{CD} 3$ & $\mathrm{CD} 4$ & CD8 & CD19 & CD56 & $\mathrm{CD} 4 / \mathrm{DR}$ & CD8/DR \\
\hline & $p g / m l$ & per $\mathrm{mm}^{3}$ & $\%$ & $\%$ & $\%$ & $\%$ & $\%$ & $\%$ & $\%$ \\
\hline $\begin{array}{l}+/+/+ \\
\quad(n=22)\end{array}$ & $408^{*}$ & $\begin{array}{c}517^{\ddagger} \\
(127-802)^{8}\end{array}$ & $\begin{array}{c}81.2 \\
(57.6-93.7)\end{array}$ & $\begin{array}{c}28.3 \\
(12.0-44.1)\end{array}$ & $\begin{array}{c}51.7 \\
(41.7-71.4)\end{array}$ & $\begin{array}{c}10.5 \\
(2.6-24.2)\end{array}$ & $\begin{array}{c}12.7 \\
(2.9-27.4)\end{array}$ & $\begin{array}{c}5.5 \\
(2.3-11.1)\end{array}$ & $\begin{array}{c}20.6 \\
(8.9-49.8)\end{array}$ \\
\hline $\begin{array}{l}-/+/+ \\
\quad(n=28)\end{array}$ & 546 & $\begin{array}{c}421 \\
(162-845)\end{array}$ & $\begin{array}{c}82.1 \\
(65.9-91.4)\end{array}$ & $\begin{array}{c}25.4 \\
(6.8-40.5)\end{array}$ & $\begin{array}{c}57.8 \\
(40.7-70.4)\end{array}$ & $\begin{array}{c}10.2 \\
(5.5-31.7)\end{array}$ & $\begin{array}{c}11.7 \\
(3.2-27.2)\end{array}$ & $\begin{array}{c}4.2 \\
(1.8-10.9)\end{array}$ & $\begin{array}{c}22.7 \\
(7.2-43.1)\end{array}$ \\
\hline $\begin{array}{l}-1-1+\text { and }-1-1- \\
(n=11)\end{array}$ & 619 & $\begin{array}{c}333 \\
(15-583)\end{array}$ & $\begin{array}{c}74.5 \\
(28.8-85.2)\end{array}$ & $\begin{array}{c}18.8 \\
(3.9-38.9)\end{array}$ & $\begin{array}{c}62.3 \\
(31.2-81.5)\end{array}$ & $\begin{array}{c}16.6 \\
(3.5-43.1)\end{array}$ & $\begin{array}{c}12.5 \\
(4.5-28.6)\end{array}$ & $\begin{array}{c}2.9 \\
(1.7-9.3)\end{array}$ & $\begin{array}{c}24.6 \\
(3.7-54.6)\end{array}$ \\
\hline
\end{tabular}

${ }^{*}$ Mean value (picograms/per milliliter). ${ }^{\ddagger}$ Median value. ${ }^{8}$ Range. 


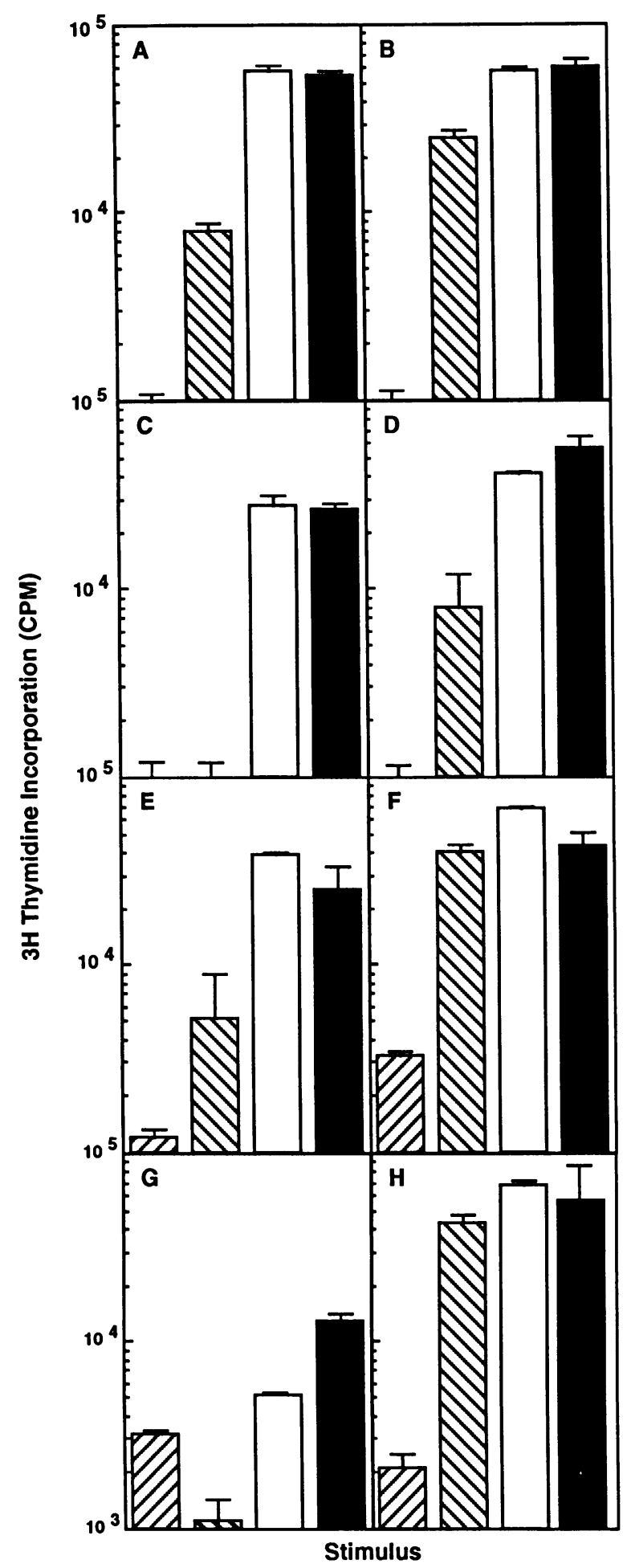

Figure 2. Proliferative responses of $\mathrm{PBMC}$ from four $\mathrm{HIV}^{+}$individuals either unstimulated ( 6$)$, or stimulated with FLU ( $\square)$, ALLO $(\square)$, or PHA ( $\square$ ). The left and right columns indicate responses in the absence or presence of $5 \mu \mathrm{g} / \mathrm{ml}$ anti-IL-10 antibody, respectively. Anti-TGF- $\beta$ antibody was used as control and did not have an effect on $\mathrm{T}$ cell proliferation.

+ ] response (Fig. 2, $C$ vs. $D$ ). Finally, a $[-/-/+]$ response was converted to $[+/+/+]$ by a $>10$-fold improvement in FLUand ALLO-stimulated proliferative responses (Fig. 2, $G$ vs. $H$ ).
Improved proliferative responses by anti-IL-10 antibody (greater than or equal to fourfold above basal response) were observed in the majority $(38 / 57 ; 67 \%)$ of the $\mathrm{HIV}^{+}$individuals tested. Similar results were obtained with anti-IL-4 antibody and with the combination anti-IL-10 plus anti-IL-4 (data not shown). Anti-TGF- $\beta$ antibody was used as a negative control and had no effect on $T$ cell proliferation (data not shown). The addition of anti-IL-10 antibody to FLU-, ALLO-, or PHA-stimulated PBMC of HIV - control did not result in changes of the proliferative response (data not shown ). Thus, anti-IL-10 can selectively enhance the proliferative responses to recall or alloantigens in the majority of $\mathrm{TH}$ functionally defective $\mathrm{HIV}^{+}$individuals.

A major objective of immune-based therapy in AIDS is the restoration or enhancement of HIV-specific immunity. Because anti-IL-10 elevated proliferative responses to FLU, we tested whether anti-IL-10 would elevate HIV-specific proliferative responses of $\mathrm{HIV}^{+}$individuals. $\mathrm{PBMC}$ from $\mathrm{HIV}^{+}$individuals and $\mathrm{HIV}^{-}$control donors were stimulated with env peptides in the absence of antibodies or in the presence of anti-IL10 , anti-IL-4, or anti-IL-10 plus anti-IL-4. The results from representative experiments (Fig. 3 ) indicate that peptide-specific proliferation by PBMC from all seven of the $\mathrm{HIV}^{+}$individuals tested was increased $3-10$-fold by anti-IL- 10 but not by anti-IL- 4 antibodies. In contrast, env peptides-specific prolifer-

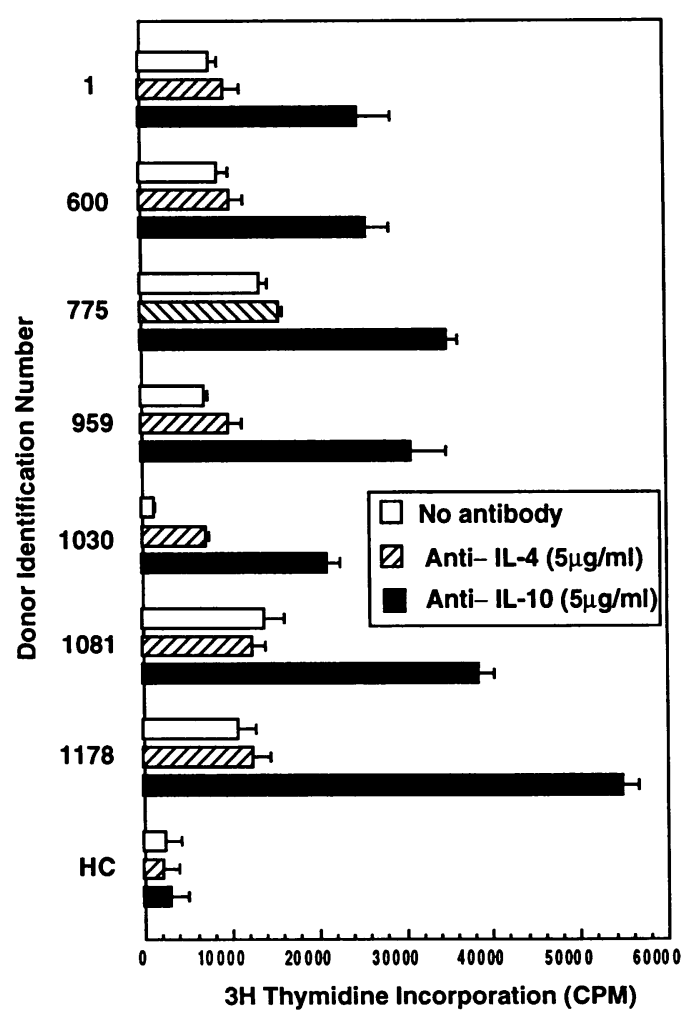

Figure 3. Proliferative responses of $\mathrm{PBMC}$ from seven $\mathrm{HIV}^{+}$individuals and one $\mathrm{HIV}^{-}$individual $(H C)$ stimulated with a pool of the HIV env peptides T1, T2, Th4.1, and P18 IIIB and P18MN. The cultures were stimulated in the absence $(\square)$ or presence of $5 \mu \mathrm{g} / \mathrm{ml}$ anti-IL-10 ( $\bullet$ ) or of $5 \mu \mathrm{g} / \mathrm{ml}$ anti-IL-4 (国) antibodies. The numbers indicated are the individuals' identification numbers. The medium alone controls for each patient, which did not exceed 1,000 cpm, were subtracted from the stimulated cultures. 


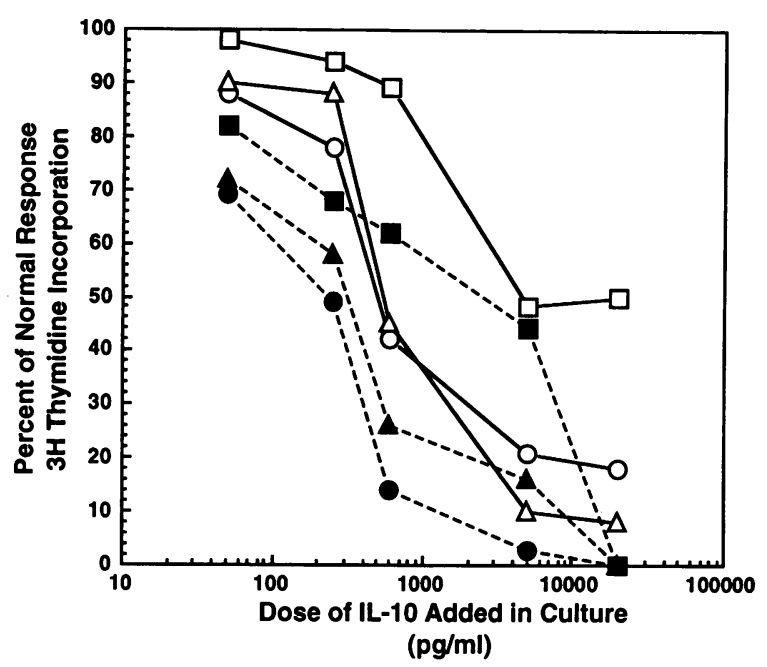

Figure 4. Effect of different concentrations of IL-10 on in vitro suppression of FLU- $(0, \bullet), \operatorname{ALLO}-(\Delta, \Delta)$, and PHA- $(\square, \bullet)$ stimulated $T$ cell proliferation. Open symbols and solid lines indicate responses by PBMC from a representative $\mathrm{HIV}^{-}$individual. Closed symbols and dashed lines indicate responses by PBMC from a representative $\mathrm{HIV}^{+}$individual. Four different titration experiments were performed with similar results.

ation by PBMC from the $\mathrm{HIV}^{-}$control was not increased and remained within the unstimulated culture range. Finally, antiIL-10 antibody did not enhance the proliferative response to the control nonimmunogenic env peptide P23 (30) (data not shown). It should be noted that PBMC from two of these $\mathrm{HIV}^{+}$individuals (959 and 1030) were unresponsive to the peptides (compared with unstimulated controls), but became responsive in the presence of anti-IL-10. Similar results were obtained by IL-2 production (data not shown). The combination anti-IL-10 plus anti-IL-4 was also effective in restoring $e n v$-specific TH function (data not shown). Thus, anti-IL-10 but not anti-IL-4 can restore the HIV-specific T cell proliferative response of PBMC in the majority $(15 / 24 ; 63 \%)$ of $\mathrm{HIV}^{+}$ individuals.

Inhibition of TH function with IL-10. The above results suggest that increased production of IL-10 by PBMC from $\mathrm{HIV}^{+}$individuals contributed to the TH dysregulation and resulted in reduced IL-2 production and proliferation to env peptides, REC, and ALLO. To test the in vitro immunosuppressive potential of IL-10, two types of experiments were performed. First, IL-10 titration curves were generated for the suppression of FLU-, ALLO-, and PHA-stimulated proliferative responses by PBMC from $\mathrm{HIV}^{-}$controls and $\mathrm{HIV}^{+}[+/+/+]$ donors. As shown in Fig. 4, $600 \mathrm{pg} / \mathrm{ml}$ of IL-10 reduced the FLU and ALLO response to $15-50 \%$ of the normal response. Of notice, these levels of IL-10 are comparable with those produced by the $[-/-1+$ and $-/-1-] \mathrm{HIV}^{+}$individuals shown in Fig. 1. PBMC from the $\mathrm{HIV}^{+}$individuals may have been more sensitive to the suppressive effects of IL-10 than PBMC from the $\mathrm{HIV}^{-}$donors. Second, PBMC from healthy, $\mathrm{HIV}^{-}$ control donors were stimulated with FLU, ALLO, and PHA, and the IL-2 generated in the culture supernatants was assessed (Fig. $5 \mathrm{~A}$ ). Parallel cultures of these PBMC were stimulated: $(a)$ without IL-10 or antibody; $(b)$ in the presence of IL-10 to determine whether IL-10 would suppress IL-2 production (Fig. $5 B) ;(c)$ in the presence of IL-10 plus anti-IL-10 antibody to determine whether the suppressive effects of IL-10 would be reversed by anti-IL-10 (Fig. $5 C$ ); and $(d)$ in the presence of IL-10 plus anti-IL-4 to determine whether IL-4 was involved in the IL-10-mediated inhibition of IL-2 production (Fig. 5 $D$ ). The results indicate that IL-10 suppressed FLU- and ALLO-stimulated IL-2 production but not PHA-stimulated IL-2 production. Furthermore, addition of anti-IL-10 but not anti-IL-4 antibody reversed the suppressive effect of IL- 10 . Similar results were obtained in five independent experiments. Thus, elevated IL-10 in vitro converts the $[+/+/+]$ phenotype of normal controls into an apparent $[-/-1+]$ phenotype, suggesting that the elevation in IL-10 observed in cells from $\mathrm{HIV}^{+}$ patients contributes to their in vitro immunological defects. Similar results were obtained for proliferative responses by FLU- and ALLO-stimulated PBMC from $\mathrm{HIV}^{-}$individuals (data not shown).

\section{Discussion}

In the mouse, IL-10 is produced by $\mathrm{TH} 2$ but not $\mathrm{TH} 1$, and IL- 10 has been shown to be a potent inhibitor of cytokine production by $\mathrm{TH} 1$, both in vitro and in vivo (12-14). This inhibition is primarily because of the action of IL-10 on antigen-presenting cell (APC) function, rather than on the TH itself (13). One consequence of this is that the amount of IFN- $\gamma$ (a TH1-

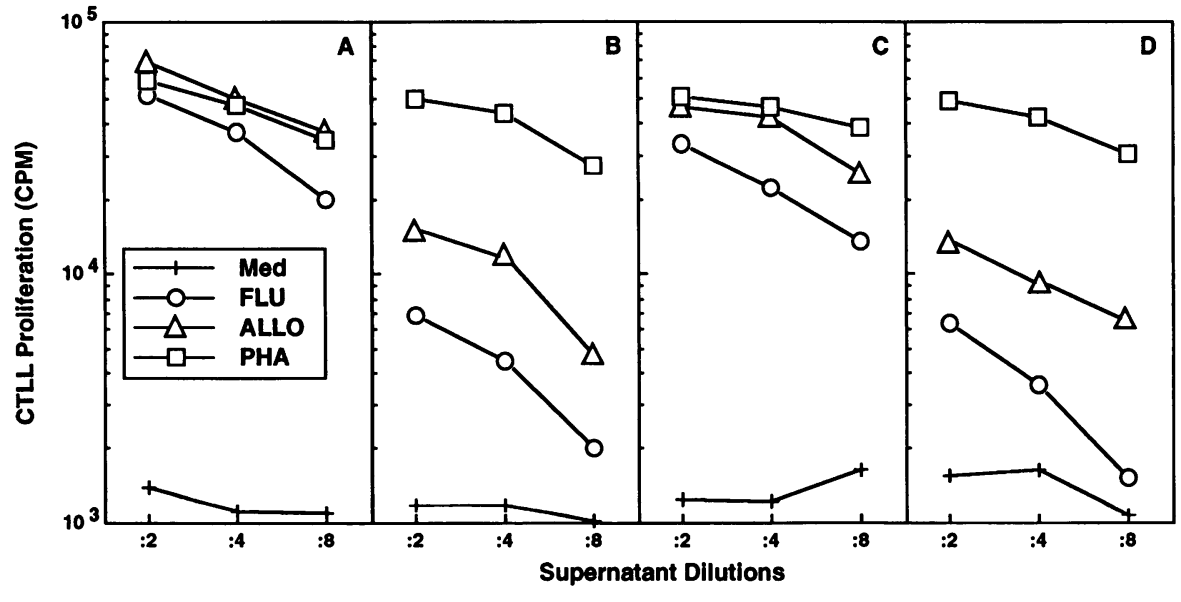

Figure 5. Effect of IL-10 and/or anti-IL-10 on IL-2 production by PBMC from an $\mathrm{HIV}^{-}$individual either unstimulated (Med) (+), or stimulated with FLU (O), $\operatorname{ALLO}(\Delta)$, or PHA (ם). $A$, untreated cultures. $B$, cultures containing $5 \mathrm{ng} / \mathrm{ml} \mathrm{IL-10.}$ $C$, cultures containing $5 \mathrm{ng} / \mathrm{ml} \mathrm{IL-10} \mathrm{and}$ $5 \mu \mathrm{g} / \mathrm{ml}$ anti-IL-10. $D$, cultures containing $5 \mathrm{ng} / \mathrm{ml} \mathrm{IL-10}$ and $5 \mu \mathrm{g} / \mathrm{ml}$ of anti-IL-4. 
like cytokine) produced by secondary in vitro cultures is frequently limited by the amount of IL-10 produced in those cultures, and IFN- $\gamma$ production can be increased severalfold by including anti-IL-10 in the cultures (Powrie, F., D: Menon, and R. L. Coffman, manuscript submitted for publication). Human IL-10 has been shown similarly to inhibit the function and proliferation of TH1-like human $\mathrm{CD}^{+}{ }^{+} \mathrm{T}$-cells. Although IL- 10 can be produced by both human $\mathrm{TH} 1$ and $\mathrm{TH} 2$ clones (20), it may be preferentially associated in vivo with responses that are predominantly $\mathrm{TH} 2$ like $(11,31)$. We present here data showing that the production of IL-2 by human PBMC is severely impaired by IL- 10 in the dose range of IL- 10 detected in the supernatants of cultured PBMC from $\mathrm{HIV}^{+}$individuals who exhibit TH dysfunction. We also demonstrate that IL-2 production in $\mathrm{HIV}^{+}$individuals can be dramatically increased by anti-IL- 10 antibodies.

In the progression of HIV infection to AIDS, we observed that a first stage characterized by loss in recall antigen-stimulated IL-2 production and increase in PHA-stimulated IL-4 production is followed by a stage identified by loss in recall and ALLO-stimulated IL-2 production and decrease in PHA-stimulated IL-4 production (4). We therefore tested whether one or more of the defects in IL-2 production would be associated with an increase in IL-10 production. We observed increases in IL-10-specific mRNA and PHA-stimulated IL-10 production in all three groups of defective patients, with the more severely immunodeficient individuals producing more IL-10.

That these defects are attributable to the immunosuppressive effects of endogenous IL-10 is supported by experiments demonstrating that proliferation and IL-2 production to FLU and $e n v$ peptides could be restored by adding anti-IL-10 to the cultures of PBMC from $\mathrm{HIV}^{+}$individuals. Conversely, the addition of IL- 10 to cultures of PBMC from $\mathrm{HIV}^{-}$donors as well as from $\mathrm{HIV}^{+}[+/+/+]$individuals resulted in a profound inhibition of FLU- and ALLO-specific proliferation, which could be reversed with anti-IL-10. Such findings argue against the possibility that these early defects in $\mathrm{TH}$ function are the result of $T$ cell energy. It appears, instead, that the type of defects in $\mathrm{TH}$ function described here are the result of active inhibition of TH function and/or of APC function and that IL-10 is a major contributor to such inhibition. Furthermore, IL-10 levels are increased in the serum of AIDS patients with non-Hodgkin's lymphoma ( 32 ), suggesting that IL-10 contributes to other AIDS-associated pathologies.

From the present and a previous study (9), it appears that predominance of a type 1-like cytokine profile is replaced by a type 2-like cytokine profile in the progression of asymptomatic HIV-infected individuals toward AIDS. Although detected in asymptomatic, $\mathrm{HIV}^{+}$individuals, this type 1-to-type 2 switch is predictive for three relevant correlates of AIDS: $(a)$ decline in CD4 counts (6); (b) time to diagnosis of AIDS (7); and (c) time to death (7). Thus, analysis of immunoregulatory cytokine profiles may be important for early diagnosis of progression to AIDS (33), as it has recently been reported that the CD4 count is an incomplete surrogate marker for the analysis of such progression $(34,35)$. Furthermore, a recent report shows that IL-4 and IL-10 have a synergistic effect favoring in vitro HIV replication in the latently infected promonocytic line U1 (36). That the viral load may be augmented in the high IL- 10 subset of $\mathrm{HIV}^{+}$individuals $[-/-1+$ and $-/-/-]$ is suggested by the finding that these same patients show a faster decline of CD4 number and progress to AIDS and to death more rapidly than the low IL-10, low IL-4 patients $[+/+/+]$. Our hypothesis that a switch from a predominant TH1-like to a predominant TH2-like functional pattern occurs in HIV infection (32) is supported by recent reports from other laboratories $(37,38)$. Our findings are also consistent with recent reports suggesting that cytokine cross-regulation is involved in $\mathrm{TH}$ dysregulation and susceptibility to infection in individuals affected by leprosy $(11,30)$, leishmaniasis $(39)$, and kala azar (22). It is nevertheless important to emphasize that anti-IL-4 antibodies and anti-IL-10 antibodies restored IL-2 production and proliferative responses in the majority, but not in all of the $\mathrm{HIV}^{+}$individuals (9, and this report). Therefore, there is a minority of $\mathrm{HIV}^{+}$individuals in whom: $(a)$ the immunosuppressive action of type 2-like cytokines is too potent to be overcome by antibodies; $(b)$ prior action of these cytokines in vivo on $\mathrm{T}$ cell clonal expansion precludes a restoration of the response in vitro; or $(c)$ the immunosuppressive action of type 2-like cytokines is associated with one or more of the alternative mechanisms possibly responsible for the suppression of TH function, before and independent of the reduction in the number of $\mathrm{CD}^{+}{ }^{+} \mathrm{TH}$ lymphocytes (40-48).

Addition of anti-IL-10, but not of anti-IL-4, also restored the proliferative response to HIV-specific antigens such as the env peptides. This discrepancy raises the possibility that the immunosuppressive potential of IL-10 is greater than that of IL-4. Such an interpretation is consistent with our observations that $\mathrm{HIV}^{+}$individuals who produce IL-4 belong to the $[-/+1$ + ] category, whereas a higher proportion of higher producers of IL- 10 belong to the $[-/-/+]$ category, in which the potent ALLO-specific TH response is suppressed. That IL-10 acts mainly by inhibiting APC function $(13,16-19)$ is consistent with our observation that IL-10 suppresses IL-2 production of PBMC from $\mathrm{HIV}^{-}$individuals in response to FLU and ALLO, antigens that require processing by APC, but not in response to PHA, a stimulus that is less dependent on APC function to induce triggering of $\mathrm{T}$ cell response.

This study provides the first example in which restoration of HIV-specific TH response was detected, either by in vitro addition of a reagent to cultures of PBMC or by in vitro testing of PBMC from HIV-infected symptomatic and asymptomatic patients who were on AIDS therapeutic protocols $(49,50)$. Because our in vitro functional characterization is predictive for three correlates of AIDS (see above) and we demonstrate here in vitro restoration of defective $\mathrm{TH}$ functional profile with anti-IL-10, our findings raise the possibility of using cytokinebased therapy for restoration of $\mathrm{TH}$ function by reversing the TH2-like prevalence over TH1-like function in $\mathrm{HIV}^{+}$patients, as it has been recently suggested (51). Thus, therapy based on counteracting the effects of IL-10 might restore HIV-specific T cell immunity, which is an objective of immune-based therapy in AIDS.

\section{Acknowledgments}

The authors wish to thank Dr. John Abrams, DNAX Research Institute, who generously provided the reagents used in this project. The authors also wish to thank Ms. Naomi Casey and Mrs. Smita Mauze for 
their excellent technical help, and Dr. Daniel R. Lucey for critically reviewing the manuscript.

The DNAX Research Institute is supported by the Schering-Plough Corporation.

\section{References}

1. Shearer, G. M., and M. Clerici. 1991. Early T helper defects in HIV infection. AIDS (Phila.). 5:245-254.

2. Lane, H. C., J. M. Depper, W. C. Greene, G. Whalen, T. A. Waldmann, and A. S. Fauci. 1985. Qualitative analysis of immune function in patients with the acquired immunodeficiency syndrome: evidence for a selective defect in soluble antigens recognition. $N$. Engl. J. Med. 313:79-84.

3. Giorgi, J. V., J. L. Fahey, D. C. Smith, L. E. Hultin, H. L. Cheng, R. T. Mitsuyasu, and R. Detels. 1987. Early effects of HIV on CD4 lymphocytes in vivo. J. Immunol. 138:3725-3730.

4. Clerici, M., N. I. Stocks, R. A. Zajac, R. N. Boswell, D. R. Lucey, C. S. Via and G. M. Shearer. 1989. Detection of three distinct patterns of T helper cell dysfunction in asymptomatic, human immunodeficiency virus-seropositive patients. Independence of $\mathrm{CD}^{+}$cell numbers and clinical staging. J. Clin. Invest. 84:1892-1899.

5. Miedema, F., A. J. C. Petit, F. G. Terpstra, J. K. M. E. Schattenkerk, F. de Wolf, B. J. M. Al, M. Roos, J. M. A. Lange, S. A. Danner, J. Goudsmit, and P. Th. A. Schellekens. 1988. Immunological abnormalities in human immunodeficiency virus (HIV)-infected asymptomatic homosexual men. HIV affects the immune system before $\mathrm{CD}^{+} \mathrm{T}$ helper cell depletion occurs. J. Clin. Invest. 82:1908-1914.

6. Lucey, D. R., G. P. Melcher, C. W. Hendrix, R. A. Zajac, D. W. Goetz, C. A. Butzin, M. Clerici, R. D. Warner, S. Abbadessa, K. Hall et al. and the U.S. Air Force HIV Study Group. 1991. The U.S. Air Force HIV study 1985-1990: immunological analyses, seroconversion and the potential utility of a T-helper functional assay to predict change in $\mathrm{CD}^{+}{ }^{+} \mathrm{T}$-cell counts during early stage HIV infection. J. Infect. Dis. 164:631-637.

7. Dolan, M. J., G. P. Melchers, M. Clerici, and G. M. Shearer. 1993. A T cell functional assay combined with measurement of $\mathrm{CD} 4{ }^{+} / \mathrm{CD} 29^{\text {bright }}$ cells is predictive of death in HIV infection. Proc. Int. Conf. AIDS., 9th. (Abstr.)

8. Clerici, M., N. I. Stocks, R. A. Zajac, R. N. Boswell, D. C. Bernstein, D. L. Mann, G. M. Shearer, and J. A. Berzofsky. 1989. IL-2 production permits detection of antigenic peptide recognition by $\mathrm{T}$ helper lymphocytes from asymptomatic, HIV seropositive individuals. Nature (Lond.). 339:383-385.

9. Clerici, M., F. T. Hakim, D. J. Venzon, S. Blatt, C. W. Hendrix, T. A. Wynn, and G. M. Shearer. 1993. Changes in interleukin-2 and interleukin-4 production in asymptomatic, human immunodeficiency virus-seropositive individuals. J. Clin. Invest. 91:759-765.

10. Maggi, E., P. Paronchi, R. Manetti, C. Simonelli, M. P. Piccinni, F. Santoni Rugiu, M. DeCarli, M. Ricci, and S. Romagnani. 1992. Reciprocal regulatory effect of IFN- $\gamma$ and IL- 4 on the in vitro development of human Th1 and Th2 clones. J. Immunol. 148:2142-2147.

11. Salgame, P., J. S. Abrams, C. Clayberger, H. Goldstein, J. Convit, R. L. Modlin, and B. R. Bloom. 1991. Differing lymphokine profiles of functional subsets of human CD4 and CD8 T cell clones. Science (Wash. DC). 254:279282.

12. Fiorentino, D. F., M. W. Bond, and T. R. Mosmann. 1989. Two types of mouse Thelper cell. IV. Th2 clones secrete a factor that inhibits cytokine production by Th1 clones. J. Exp. Med. 170:2081-2095.

13. Fiorentino, D. F., A. Zlotnik, P. Vieira, T. R. Mosmann, M. Hoeard, K. W. Moore, and A. O'Garra. 1991. IL-10 acts on the antigen-presenting cells to inhibit cytokine production by Th1 cells. J. Immunol. 146:3444-3451.

14. Moore, K. W., A. O'Garra, R. de Waal Malefyt, P. Vieira, and T. R. Mossman. 1993. Interleukin-10. Annu. Rev. Immunol. 11:165-190.

15. Scott, P., and S. H. E. Kaufmann. 1991. The role of T-cell subsets and cytokines in the regulation of infection. Immunol. Today. 12:346-348.

16. de Waal Malefyt, R., J. Hannen, H. Spits, M.-G. Roncarolo, A. te Velde, C. Figdor, K. Johnson, R. Kastelein, H. Yssel, and J. E. de Vries. 1991. Interleukin 10 (IL-10) and viral IL-10 strongly reduce antigen-specific human T cell proliferation by diminishing the antigen-presenting capacity of monocytes via downregulation of class II major histocompatibility complex expression. J. Exp. Med. 174:915-924.

17. de Waal Malefyt, R., J. Abrams, B. Bennett, C. G. Figdor, and J. E. de Vries. 1991. Interleukin 10 (IL-10) inhibits cytokine synthesis by human monocytes. An autoregulatory role of IL-10 produced by monocytes. J. Exp. Med. 174:1209-1220.

18. Bogdan, C., Y. Vodovotz, and C. Nathan. 1991. Macrophage deactivation by interleukin 10. J. Exp. Med. 174:1549-1555.

19. Taga, K., and G. Tosato. 1992. IL-10 inhibits human T cell proliferation and IL-2 production. J. Immunol. 148:1143-1149.
20. Del Prete, G., M. De Carli, F. Almerigogna, M. G. Giudici, R. Biagiotti, and S. Romagnani. 1993. Human IL-10 is produced by both type 1 helper $T$ clones and type 2 helper $\mathrm{T}$ clones and inhibits their antigen-specific proliferation and cytokine production. J. Immunol. 150:353-360.

21. Wynn, T. A., I. Eltoum, A. W. Cheever, F. A. Lewis, W. C. Gause, and A. Sher. 1993. Analysis of cytokine mRNA expression during primary granuloma formation induced by eggs of Schistosoma mansoni. J. Immunol. 150:37073712.

22. Karp, C. L., S. H. El-Safi, T. A. Wynn, M. M. H. Satti, A. M. Kordofani, F. A. Hashim, M. Hag-Ali, F. A. Neva, T. B. Nutman, and D. L. Sacks. 1993. In vivo cytokine profiles in patients with Kala-azar. Marked elevation of both interleukin-10 and interferon-gamma. J. Clin. Invest. 91:1644-1648.

23. Clerici, M., C. O. Tacket, C. S. Via, D. R. Lucey, S. C. Muluk, R. A. Zajac, R. N. Boswell, J. A. Berzofsky, and G. M. Shearer. 1991. Immunization with subunit HIV vaccines generates stronger $T$ helper cell immunity than natural infection. Eur. J. Immunol. 21:1345-1349.

24. Cease, K. B., H. Margalit, J. L. Cornette, S. D. Putney, W. G. Robey, C. Ouyang, H. Z. Streicher, P. J. Fishinger, R. C. Gallo, C. DeLisi, and J. A. Berzofsky. 1987. Helper T-cell antigenic site identification in the acquired immunodeficiency syndrome virus $\mathrm{gp} 120$ envelope protein and induction of immunity in mice to the native protein using a 16-residue synthetic peptide. Proc. Natl. Acad. Sci. USA. 84:4249-4253.

25. Hale, P. M., K. B. Cease, R. A. Houghten, C. Ouyang, S. Putney, K. Jahaverian, H. Margalit, J. L. Cornette, J. L. Spouge, C. DeLisi, and J. A. Berzofsky. 1989. T cell multideterminant regions in the human immunodeficiency virus envelope: toward overcoming the problem of major histocompatibility complex restriction. Int. Immunol. 1:409-415.

26. Takahashi, H., J. Cohen, A. Hosmalin, K. B. Cease, R. Houghten, J. L. Cornette, C. DeLisi, B. Moss, R. N. Germain, and J. A. Berzofsky. 1989. An immunodominant epitope of the human immunodeficiency virus envelope glycoprotein gp 160 recognized by class I major histocompatibility complex molecule-restricted murine cytotoxic T lymphocytes. Proc. Natl. Acad. Sci. USA. 85:3105-3109.

27. Uchiyama, T., S. Broder, and T. A. Waldmann. 1981. A monoclonal antibody (anti-Tac) reactive with activated and functionally mature human $T$ cell. I. Production of anti-Tac monoclonal antibody and distribution of Tac $(+)$ cells. J. Immunol. 126:1393-1399.

28. Abrams, J. S., M. G. Roncarolo, H. Yssel, U. Andersson, G. J. Gleich, and J. E. Silver. 1992. Strategies of anti-cytokine monoclonal antibody development: immunoassay of IL-10 and IL-5 in clinical samples. Immunol. Rev. 127:5-48.

29. Centers for Disease Control. 1992. Guidelines for the performance of $\mathrm{CD}^{+} \mathrm{T}$-cell determinations in persons with human immunodeficiency virus infection. Morbidity Mortality Weekly Report. 41:1-17.

30. Clerici, M., J. V. Giorgi, C. C. Chou, V. K. Gudeman, J. A. Zack, P. Gupta, H.-N. Ho, P. G. Nishanian, J. A. Berzofsky, and G. M. Shearer. 1992. Cell mediated immune response to human immunodeficiency virus type 1 (HIV-1) in seronegative homosexuals with recent sexual exposure to HIV-1. J. Infect. Dis. 165:1012-1019.

31. Yamamura, M., K. Uyemura, R. J. Deans, K. Weinberg, T. H. Rea, B. R. Bloom, and R. L. Modlin. 1991. Defining protective responses to pathogens: cytokine profiles in leprosy lesions. Science (Wash. DC). 254:277-279.

32. Benjamin, D., T. J. Knobloch, and M. A. Dayton. 1992. Human B-cell interleukin-10: B-cell lines derived from patients with AIDS and Burkitt lymphoma constitutively secrete large quantities of interleukin-10. Blood. 80:12891299.

33. Clerici, M., and G. M. Shearer. 1993. Is HIV associated with a THI $\rightarrow$ TH2 switch? Immunol. Today. 14:107-111.

34. Subsung, C., S. W. Lagakos, R. T. Schooley, and P. A. Volberding. 1993. $\mathrm{CD}^{+}$lymphocytes are an incomplete surrogate marker for clinical progression in persons with asymptomatic HIV infection taking Zidovudine. Ann. Intern. Med. 118:674-685.

35. Phair, J. P. 1993. Estimating prognosis in HIV-1 infection. Ann. Intern. Med. 118:742-744.

36. Poli, G., L. Kinter, D. Weissman, P. Biswas, and A. S. Fauci. 1993. Interaction between pro-inflammatory and immunoregulatory cytokines modulates the expression of human immunodeficiency virus in monocytic cells. Clin. Res. 41:221a. (Abstr.)

37. Ferrari, G., M. V. Packard, J. A. Bartlett, and K. J. Weinhold. 1993. TH1 and TH2 CD4 subset responses in HIV-1 infected individuals at various stages of the disease. J. Cell. Biochem. 78:Q520a. (Abstr.)

38. Meyaard, L., H. Shuitemaker, and F. Miedema. 1993. T-cell dysfunction on HIV infection: anergy due to defective antigen-presenting cell function? Immunol. Today. 14:161-165.

39. Pirmez, C., M. Yamamura, K. Uyemura, M. Paes-Oliveira, F. ConceiçãoSilva, and R. L. Modlin. 1993. Cytokine patterns in the pathogenesis of human leishmaniasis. J. Clin. Invest. 91:1390-1395.

40. Diamond, D. C., B. P. Sleckman, T. Gregory, L. A. Lasky, J. L. Green- 
stein, and S. J. Burakoff. 1988. Inhibition of $\mathrm{CD}^{+} \mathrm{T}$ cell function by the envelope glycoprotein gp 120. J. Immunol. 141:3715-3719.

41. Weinhold, K. J., H. K. Lyerly, S. D. Stanley, A. A. Austin, T. J. Matthews, and D. P. Bolognesi. 1989. HIV-1 gp120-mediated immune suppression and lymphocyte destruction in the absence of viral infection. J. Immunol. 142:30913096.

42. Schnittman, S. M., H. C. Lane, J. Greenhouse, and A. S. Fauci. 1990. Preferential infection of $\mathrm{CD}^{+} \mathrm{T}$ memory cells by human immunodeficiency virus type I: evidence for a role in the selective $\mathrm{T}$ cell functional defects observed in infected individuals. Proc. Natl. Acad. Sci. USA. 87:6058-6063.

43. Laurence, J., A. B. Gottlieb, and H. G. Kunkel. 1983. Soluble suppressor factors in patients with acquired immunodeficiency syndrome and its prodrome. Elaboration in vitro by T lymphocyte-adherent cell interactions. J. Clin. Invest. 72:2072-2081.

44. Clerici, M., E. Roilides, C. S. Via, P. A. Pizzo, and G. M. Shearer. 1992. A factor from CD8 cells of human immunodeficiency virus (HIV)-infected patients suppresses HLA self-restricted T helper cell responses. Proc. Natl. Acad. Sci. USA. 89:8424-8429.

45. Viscidi, R. P., K. Mayur, H. M. Lederman, and A. D. Frankel. 1989. Inhibition of antigen-induced lymphocyte proliferation by Tat protein from HIV-1. Science (Wash. DC). 246:1606-1609.
46. Kekow, J., W. Wachsman, A. McCutchan, W. L. Gross, M. Zachariah, D. A. Carson, and M. Lotz. 1990. Transforming growth factor-b and noncytopathic mechanisms of immunodeficiency in HIV infection. Proc. Natl. Acad. Sci. USA. 87:8321-8326.

47. Mittler, R. S., and M. K. Hoffmann. 1989. Synergism between HIV gp 120 and $\mathrm{gp} 120$ specific antibody in blocking human $\mathrm{T}$ cell activation. Science (Wash. DC). $245: 1380-1383$

48. Golding, H., G. M. Shearer, K. Hillman, P. Lucas, J. Manischewitz, R. A. Zajac, M. Clerici, R. E. Gress, R. N. Boswell, and B. Golding. 1989. Common epitope in human immunodeficiency virus (HIV) I-gp4l and HLA class II elicits immunosuppressive autoantibodies capable of contributing to immune dysfunction in HIV I-infected individuals. J. Clin. Invest. 83:1430-1435.

49. Clerici, M., E. Roilides, K. M. Butler, L. DePalma, D. V. Venzon, G. M. Shearer, and P. A. Pizzo. 1992. Changes in T helper cell function in human immunodeficiency virus infected children during dideoxynosine therapy as a measure of antiretroviral activity. Blood. 80:2196-2202.

50. Clerici, M. A. Landay, H. Kessler, D. V. Venzon, D. R. Lucey, and G. M. Shearer. 1992. Reconstitution of T helper cell function following zidovudine therapy in HIV infected patients. J. Infect. Dis. 166:723-730.

51. Bloom, B. R. 1993. The power of negative thinking. J. Clin. Invest. 91:1265-1266. 